\title{
NEW PERSPECTIVES FOR THE DISSEMINATION \\ OF MEDIEVAL HISTORY: RE-ENACTMENT IN SOUTHERN EUROPE, A VIEW FROM THE PERSPECTIVE OF DIDACTICS
}

\author{
DARÍo ESPAÑol \\ UNIVERSIDAD DE ZARAGOZA \\ SPAIN
}

Date of receipt: $11^{\text {th }}$ of December, 2017

Final date of acceptance: $10^{\text {th }}$ of April, 2018

\begin{abstract}
Historical re-enactment has arisen in recent years as an important tool for the dissemination of mediaeval history. However, in Spain a debate has developed around its consideration as a philanthropic practice or as a discipline assisted by historic method that may serve as a means for researching or communicating the past. Is this a valuable tool for the dissemination of mediaeval history? This article analyses the virtues and deficiencies of a model that has its roots in the Englishspeaking world, and which in Spain has been eclipsed by other archetypes rooted in folklore and popular festivals. We will reflect on the role that may be played by didactics to transform this, to a certain extent undervalued, resource.
\end{abstract}

\section{KeYWORDS}

Historical re-enactment, Didactics in the Social Sciences, dissemination, Middle Ages, didactical museography.

\section{Capitalia Verba}

Repraesentatio historica, Disciplina in socialibus scientiis, Dissemination, Medium aevum, Disciplina museographica. 


\section{Introduction}

Enseñar no tiene otro sentido que mostrar cómo difieren las cosas en sus diferentes propósitos, formas y origenes. Por lo tanto, quien diferencia bien, enseña bien. ${ }^{1}$ With this quotation from his Didactica Magna, not pronounced by chance, John Amos Comenius lay the epistemological foundations for the teaching of scientific knowledge. Henceforth, it would not be a question merely of what we teach, but of how we teach, making methodological aspects the fundamental basis for any educational process.

With this article, I set out to approach how knowledge of the Middle Ages is being disseminated in southern Europe through the practice of historical re-enactment. The analysis will focus not only on the efforts made in recent decades in this respect but will also examine the new routes being taken by this method of disseminating the Middle Ages, with trends that compete with and exceed traditional initiatives for knowledge transfer. Thus, we will try to offer an analysis from the perspective of didactics, or, to put it another way: of the methodological processes that give rise to teaching-learning situations, developed in informal contexts and which, despite germinating from an interest in the simple dissemination of history, propose spaces for knowledge that make it possible to decode our mediaeval past and which could be included among the resources inherent to this scientific-pedagogic discipline. We will analyse the methodological premises with which mediaeval re-enactment is approached by the different groups by which it is performed, and whether we are really in the presence of a formally-constituted phenomenon by which to disseminate the past or rather a hobby that, tangentially, exercises dissemination in a complementary manner. The key, in this respect, will be to uncover the didactic elements in the development of this practice and to examine what should be present in the event that this is solely and exclusively a tool to educate on the past.

Currently the conception of re-enactment is related to diverse segments of activity. The performers themselves define what they do and why they do it in very different ways, and this establishes, to a certain extent, the way in which they re-enact. Indeed, the assumption of this discipline alternates between various relational areas imposed by the nature, training and aspirations of the performers. These areas include, for example, the scenic arts, narrative practices (such as role plays), education, dissemination, ${ }^{2}$ scientific research (and its ties to

\footnotetext{
1. "To teach means scarcely anything more than to show how things differ from one another in their different purposes, forms and origins. Therefore, he who differentiates well teaches well". Comenius, Jan Amos. Didactica magna, transl. Saturnino López Peces. Madrid: Ediciones Akal, 1986: 133 (Chapter 16: Requisitos generales para aprender y enseñar. Esto es: De qué modo debemos enseñar y aprender con tal seguridad y necesariamente hayan de experimentarse los efectos).

2. This aspect is dealt with, almost exclusively, by the work of Cózar, in: Cózar Llistó, Guillermo. “La Recreación Histórica en España. Definición, caracterización y perspectivas de aplicación". Glyphos: Revista de Arqueología, 2 (2013): 9-11, in which he establishes a methodology for the systematisation of the practice from research to re-enactment, in order to preserve history. Also interesting, along the same lines, is: Agnew, Vanessa. "Introduction: what is reenactment?". Criticism, 46/3 (2004): 327-339. And at a less specialised level: Cabrera Asensio, Jonathan. "Las recreaciones históricas y sus fundamentos: (qué es, quiénes somos, cómo crearlas)". ASRI: Arte y sociedad. Revista de investigación, 3 (2013).
} 
experimental archaeology), museology and museography, or philanthropic aims. ${ }^{3}$ Some, when they recreate, assume that they are actors and they interpret roles. Others, however, do so only to disseminate the past, therefore they concentrate on aspects of daily life or models, interpreting characters without identity, casting aside any allusions related to the interpretation and assumption of roles. Some examples of this would be reconstructing how dyes were made to dye clothes in the $12^{\text {th }}$ century, reaping a field of wheat as it was done in Catalonia in the $15^{\text {th }}$ century, or illuminating and writing in an empty codex with rotunda script for the choir of an abbey while dressed in Benedictine habits. And there are also those who recreate solely and exclusively to research the past in order to subsequently publish what has been experienced or to submit it to debate. In any case, it is assumed that the practice of historical re-enactment implies some unavoidable conditioning factors by which it differs from an ordinary theatrical play or performance. Ultimately it goes beyond mere entertainment. In fact, those who recreate coincide in that historical re-enactment is, solely and exclusively, the practice of reconstructing uses, customs, material culture and aspects of the past based on specifically scientific norms, to achieve objectives related to cultural dissemination and education. Historical re-enactment differs, therefore, from other manifestations related to history that lack this scientific support and the indissoluble factor of dissemination.

In this process various factors come into play, if we look at the definition provided. Of these, three, in particular, stand out: 1) research, 2) dissemination and 3) education. With regard to the re-enactment of the Middle Ages, not only in the southern European countries such as Spain, Portugal or Italy, but also in the rest of the continent, we will see that these three factors structure the framework in a very distinct way, and even on the basis of the inexistence of one or more of them.

As a consequence, one of the main aims of this study will be to look in depth at which heuristic procedures are adopted beforehand in order to practice the reenactment of mediaeval history; which resources, skills and actions are used to achieve the dissemination of the past which is supposedly recreated; and which didactic methodologies are implemented, in the event that they are included in the development of the practice.

\footnotetext{
3. The inclinations, uses and different developments of historical re-enactment are dealt with thoroughly in the work of Jay Anderson, probably one of the authors who has examined this topic in greatest depth at global level: Anderson, Jay. A Living History Reader. Nashville: American Association for State $\delta$ Local History, 1991: 3-12 (Chapter 1: "Living history"); Anderson, Jay. Time machines: The world of living history. Nashville: American Association for State \& Local History, 1984; Anderson, Jay. "Living history: Simulating everyday life in living museums". American Quarterly, $34 / 3$ (1982): 290-306; Anderson, Jay. The living history sourcebook. Nashville: American Association for State \& Local History, 1985.
} 


\section{Regarding concepts}

In any of the scenarios with which we closed the previous chapter, the concept of historical re-enactment is linked to that of "living history", ${ }^{4}$ which is simply the result of reconstructing, staging and bringing back to life historical scenes. Thus, this concept is usually adapted to heritage spaces, museums or educational contexts, since its use is not unusual (especially in central and northern Europe) in castles, archaeological ruins, religious architecture, palaces and other heritage assets as the main attraction of their cultural offering.

It is appropriate to situate, albeit superficially, the origin of mediaeval reenactments in Mediterranean societies. Recreating history is not a recent practice. It is fitting to remember the custom in Ancient Rome of representing scenes from the past to magnify the glory of the civilisation; these great events included the representation of feats of arms such as naumachiae, battles and other great undertakings. ${ }^{5}$ Although it is less widely known, just as Rome reconstructed its glories, mediaeval European societies did likewise with their own, and the Iberians, specifically, did so with relative frequency.

The ideological component has been the main factor behind the practices of commemorating the past by re-enactment. Since the $15^{\text {th }}$ century, in an official and institutionalised manner, Mediterranean Europe has re-enacted its immediate past to reinforce its own cultural, political and religious nature. Thus, Spain, Italy and Portugal filled their festive and public events with representations of victories against the Moors. These re-enactments adopted different aspects, such as battles, parades, games, tournaments or dances. As early as the $16^{\text {th }}$ century, the Habsburg monarchs normalised these practices in Spain with shows and pageantry that responded to a totally ideological motive: to justify and extol their Christian empire against the Muslim past, defeated long ago, for the glory of the civilisation led by the Christian princes. The roots of today's festivals of Moors and Christians lie in this Mediterranean tradition, despite the fact that the origin of the current celebrations in Spain dates from the $19^{\text {th }}$ century. In any case, this mediaeval and renaissance model gradually replaced the ideological factor that propitiated them until they fell out of favour as of the $18^{\text {th }}$ century, when their practice was restricted to rural environments, to be subsequently revived on the basis of a festive model such as that which still prevails. ${ }^{6}$ In any case, the phenomenon of the festivals

\footnotetext{
4. "Living history" is the original designation in English.

5. For further information on the projection of events of this type in Ancient Rome, and their ideological conditioning factors, see: Auguet, Roland. Crueldad y civilización: los juegos romanos. Barcelona: Aymá, 1972: p. 57; and Blázquez, José María. "Circo y fieras en la Roma antigua. Pantomimas y naumaquias". Jano, 119 (1974): 91-97.

6. Understanding the sociological phenomenon of the festivals of Moors and Christians today is linked to the dualist concept that gives them their meaning. All in all, a notable aspect in this tradition is that this dualism was already present as a festive germ in the archaic mediaeval and renaissance practices, when dozens of practices were staged around this dichotomy, such as those known as Morescas, Morismas or Soldadescas, and even in mediaeval tournaments, the Hispanic nature of which was that of representing this dualism via, for example, the lance combats known as juegos de cañas. Precedents can also be found
} 
of Moors and Christians is the irrefutable proof of the coexistence of an ancient tradition alongside the contemporary phenomenon of historical re-enactment. Reenactment, compared with this type of folkloric events, is seen as a different, distant, alien practice. Contrast is seen not only in the enormous differences between both practices with regard to costumes, props and staging, but in their very development. They differ not only in purpose, but also in form. Re-enactment has taken history from the shelves, has made it palpable, brought it back to life and shows it to society to provide knowledge with supposed scientific guarantees. The festivals of Moors and Christians seek, and have sought, to maintain a cultural and folkloric tradition based on our past, but they lack informative spirit and scientific process in their articulation and implementation. Through re-enactment, by way of example, we can explain why it is convenient to cook goose feathers in sand, as in the Middle Ages, before using them as quills for writing. ${ }^{7}$ By means of festivals of Moors and Christians we cannot explain any of this; in fact, we do not attempt to explain anything by means of these festivals, they serve a different purpose. However, although they diverge with regard to "why" and "how", they do not differ with regard to "what". So different, yet so alike. How have we changed?

If, as we have seen, the origin of the phenomenon of re-enactment lies in the dawn of the Middle Ages, the origin of modern historical re-enactment is situated just a few decades ago. It began in the United States, specifically in the 1960s. It was during these years that the American Civil War (1861-1865) began to be commemorated by means of historical re-enactments. From then on, the number of groups and associations dedicated to this discipline began to grow and diversify, with societies and federations being formed at national level, a model that then spread to Europe shortly afterwards. ${ }^{8}$ In Spain, this cultural disembarkation can be situated in the middle of the 1990s, when the first ancient and mediaeval reenactment groups began to form. ${ }^{9}$

However, we cannot say that the interests and motives of the groups that stage mediaeval re-enactments are the same; we referred to this in the introductory chapter. Although the ultimate purpose of re-enactment is exclusively dissemination, many groups that re-enact the Middle Ages lack serious and solid assumptions in this respect, when they do not contribute to glorifying other types of historical events of doubtful rigor. Furthermore, it is ascertained from circles and forums of mediaeval re-enactors that historical re-enactment, in Spain, boasts of an eminently didactic vocation, but in practice this is often not the case, since the great majority of those

in the religious tradition linked to the actual rites of the specific liturgies, as in the case of the vignettes, or sainetes, of Corpus Christi in the $15^{\text {th }}$ century. See: Albert-Llorca, Marlène; González Alcantud, José Antonio, eds. Moros y cristianos: representaciones del otro en las fiestas del Mediterráneo occidental. Toulouse: Presses Universitaires du Mirail, 2003.

7. They could not otherwise be used for writing.

8. Cortadella, Jordi. "Los grupos de recreación histórica (historical re-enactment)", La guerra en la Antigüedad desde el presente, Jordi Vidal, Borja Antela, eds. Zaragoza: Libros Pórtico, 201 1: 94.

9. Balbás, Yeyo. "La Recreación Histórica". Despertaferro-ediciones.com. 24 July 2015. Ediciones Desperta Ferro. 17 November 2017 <https://www.despertaferro-ediciones.com/2015/07/24/recreacion-historica/>. 
who practice this discipline are not familiar with the methodological principles that turn a demonstrative process into a didactic resource. To practice didactics, it is not enough to dress with more or less historical accuracy and live as in the Middle Ages.

For this it is necessary to clarify some of the concepts that intervene in the final result of the practice of historical re-enactment when it is accompanied by the dissemination of history and heritage. These terms include dissemination, interpretation and didactics, which are by no means synonymous.

The Dictionary of the Royal Spanish Academy (Diccionario de la Real Academia Española) understands divulgación ("dissemination") as Publicar, extender, poner al alcance del público algo. ${ }^{10}$

Does historical re-enactment disseminate? Nothing makes us think otherwise, if it is performed with the aim of explaining what is done, and contextualising it in the environment in which it is being done if this is important for the practice itself. In this case, the level of projection would be the same as that represented by the communications media, non-specialised literature, videogames, role-playing games, cinema, documentaries or other traditional resources. ${ }^{11}$ Dissemination, therefore, is no more than the act of transforming scientific knowledge into a processed construct that makes it possible to awaken the interest of a non-specialised audience. But there is no guarantee that this knowledge will be assimilated, learned, adopted or subsequently used by this seduced audience. ${ }^{12}$

10. "Publish, extend, make something available to the public". "Divulgar". Real Academia de la Lengua Española. 1 December 2017. <https://dle.rae.es/?id=Elq9Jgy>.

11. The bibliography of analysis on the dissemination of history and heritage in the Middle Ages is extensive, and we do not aim to offer a detailed study of the extent of the scientific studies in this respect, although as an introduction to knowledge in this field we recommend: Martín Guglielmino, Marcelo. "Reflexiones en torno a la difusión del Patrimonio Histórico", Difusión del Patrimonio Histórico, Marcelo Martín Guglielmino, ed. Seville: Junta de Andalucía, 1996: 14-27; Martín Guglielmino, Marcelo. "Difusión del Patrimonio I: La Historia". PH. Boletín del Instituto Andaluz del Patrimonio Histórico, 5 (1993): 6-7; and Martín Guglielmino, Marcelo. “La difusión del patrimonio. Actualización y debate". e-rph-Revista electrónica de Patrimonio Histórico, 1 (2007): 195-215, from a generalist perspective. Jiménez Alcázar, Juan Francisco. “Videojuegos y Edad Media". Imago temporis: Medium Aevum, 3 (2009): 551-587, with regard to videogames. Hernández Corchete, Sira. La historia contada en televisión. El documental televisivo de divulgación histórica en España. Barcelona: Gedisa, 2008; Barrio, Juan Antonio. “La Edad Media en el cine del siglo XX". Medievalismo, 15 (2005): 241-268; Alonso, Juan José; Alonso, Jorge; Mastache, Enrique. La Edad Media en el cine. Madrid: T \& B Editores, 2007; and Navarro Espinach, Germán. “Cultura Visual y enseñanza de la historia. La percepción de la Edad Media". EARI - Educación Artística Revista de Investigación, 2 (2011): 153-160, with regard to the Middle Ages in film and television. And Millán, $\mathrm{M}^{\mathrm{a}}$ Dolors. "La simulación y la representación de la realidad", Estrategias de simulación: Ora, un modelo innovador para aprender del medio, Saturnino de la Torre, ed. Barcelona: Octaedro, 1997, if we wish to know more about games and simulation processes in the dissemination of this period; this latter article, also with perspectives for didactics.

12. Regarding the exclusively informative function of re-enactment see: Cózar Llistó, Guillermo, "La Recreación Histórica...": 9-11; Del Barco Díaz, Miguel. “La recreación histórica como medio para la divulgación de la historia", La Divulgación de la Historia y otros estudios sobre Extremadura, Félix Iñesta Mena, ed. Llerena: Sociedad Extremeña de la Historia, 2010: 243-254; and Rojas Rabaneda, Antonio. "Herramientas y estrategias de difusión del Patrimonio Histórico: los eventos de recreación histórica en Cataluña". e-rph-Revista electrónica de Patrimonio Histórico, 9 (2011): 89-1 10. 
The concept of interpretation of heritage was coined by Freeman Tilden in 1977,13 and he says that it is:

Una actividad educativa que pretende revelar significados e interrelaciones mediante el uso de objetos originales, experiencias de primera mano y medios ilustrativos, en lugar de simplemente transmitir la información de los hechos. ${ }^{14}$

From this definition it is ascertained, first of all, that to interpret the past a conscious intermediation is necessary that prioritises strategies based on additional resources over the mere explanation of any scientific knowledge or content. Tilden, however, asserts that the act of interpretation in itself is already an educational action, which could carry the discussion to a different context from that which concerns us here. ${ }^{15}$ In any case it is evident that this interpretative process requires the projection of a methodology for its application. Historical re-enactment, taken as one of these strategies for the interpretation of the past, has many possibilities in this respect, despite the fact that in the majority of cases this interpretational process is not carried out with original objects, but with the evocation of material culture, customs and attitudes of the past. Likewise, the perspective changes if we take historical re-enactment as the protagonist in the intermediation of this interpretative action; not the end with which to interpret, but the means. And for this it is essential to link this practice with the heritage itself, in the context of either museums or buildings (monuments, archaeological sites...).

If we accept that historical re-enactment constitutes one of the most efficient strategies for the interpretation of the past, it is necessary to analyse whether this is also true with regard to its use as a didactical methodology for the teaching of history.

Didactics is a scientific-pedagogic discipline that studies the techniques and methods of teaching. Comenius defined it as the art of teaching, or artificio universal para enseñar todas las cosas a todos con rapidez, alegría y eficacia. ${ }^{16}$ Indeed, didactics

13. In his work, now a cult publication: Tilden, Freeman. La interpretación de nuestro patrimonio. Pamplona: Asociación para la interpretación del patrimonio, 2015.

14. An educational activity that sets out to reveal meanings and interrelationships via the use of original objects, first-hand experiences and illustrative media, instead of simply transmitting the information regarding the facts. Tilden, Freeman. La interpretación...: 37.

15. In order for an educational act to take place, a transfer is necessary, that is, el efecto de un aprendizaje previo sobre uno nuevo o sobre la resolución de un problema ("the effect of prior learning on new learning or on problem solving"); and for this to occur via what is known as significant learning. See Mayer, Richard E. Psicología de la Educación. Enseñar para un aprendizaje significativo. Madrid: Pearson, 2004: II, 7. Tilden's method lacks, a priori, a pedagogic study that allows us to guarantee the use of a fully educational methodology in this interpretation process. This does not imply that the interpretation of heritage in the terms proposed by Tilden is not a valid premise for education, on the contrary: Llonch Molina, Nayra; Santacana Mestre, Joan. Claves de la museografía didáctica. Lleida: Milenio, 2011: 42-43, especially if we observe that it is the basis for what is known as emerging museology: Llonch Molina, Nayra; Santacana Mestre, Joan. Claves de la museografía...: 143 and ss.

16. "The whole art of teaching all things to all men with certainty, pleasantly and thoroughly". Comenius, Jan Amos. Didactica...: 163. 
concerns the strategies put into practice by the main theorists of pedagogy, therefore it should ensure that learning exists. Neither dissemination nor interpretation guarantees the existence of solid and lasting learning of history; didactics, therefore, is used in creating a transformation in the mind of the audience. As a discipline with a scientific foundation inserted in education sciences it needs a method, which leads us to ask ourselves: Is didactics all that surrounds the practice of historical re-enactment? No, as we will analyse below; not even, on occasions, the part that most boasts of this. Can it be a resource for didactics? Yes, but it is necessary to make changes in the current focus of mediaeval re-enactment in order for this to be the case without reservations.

\section{Regarding models}

Almost since its modern beginnings, the practice has become hierarchically structured with regard to the level of authenticity. In its formal circles three levels or categories are established, which are known in English as: farb, mainstream and progressive, the latter also being referred to as hardcore. ${ }^{17}$ It has also been associated with other terms, such as elite warrior. ${ }^{18}$

But if what we seek is an in-depth reflection from the point of view of the management of cultural heritage and the dissemination of scientific knowledge in relationship with the phenomenon of mediaeval historic re-enactments in southern Europe, we need to embark on the real debate that currently concerns this, which is none other than that of models. Returning to folkloric traditions which, as we have seen, have their roots in the festivals of Moors and Christians, the real phenomenon that has blurred the practice of re-enactment in Spain as an element of historic dissemination has been the appearance, in the 1980s, of a typically Iberian model: historical fairs. Historical fair and historical re-enactment are not synonyms, despite the fact that they are frequently erroneously compared. In fact, they correspond to two models that are, if anything, opposed with regard to the dissemination of history. We could say that there is at present a cultural iron curtain in Europe. This frontier would leave on one side the south of Europe and its historical fairs and, on the other side, the centre and north of Europe and English-speaking countries

17. These three scales refer to the level of authenticity of the re-enactor. Thus, farbs are those whose concern for full historic rigor would take second place; mainstream re-enactors make up the majority of the re-enactment community, with a greater interest in this authenticity; and progressives include the purist re-enactors, who set out to live a total immersion in the past. By way of example, the latter knit and sew their costumes by hand, they use totally handcrafted elements, select natural fibres and even dye them using totally historic methods. For further information on the terminology and the controversy that sometimes arises, see: Hodges, Phil. "Inglorious farb'terds". War History Online. 18 April 2015. War History Online. 17 November 2017 <https://www.warhistoryonline.com/articles/inglorious-farbsterdsby-phil-hodges.html>.

18. Referring to re-enactors keen on battles and combats, owing to their connection to leather and steel: Balbás, Yeyo. "La Recreación...". 
with regard to historical re-enactment. As always occurs, the phenomenon of historical fairs is inherent to all the countries of the old continent, ${ }^{19}$ however, it is in countries such as Spain, Italy, France and Portugal where real cultural industries have been developed in this respect.

In Spain, historical fairs have become consolidated as a very powerful industry, with turnovers that other cultural industries would like to see. There are numerous examples that attract thousands of people every time they are held, such as Mediaeval Week in Montblanc (Tarragona); the Carthaginians and Romans festival (Cartagena), one of the most important events by volume of actions and participants, which was created in 1989; the Festa del Renaixement of Tortosa, held for the first time in 1996; or the celebration of the Marriage of Isabel de Segura, known as the Lovers of Teruel, also set in the mediaeval era. We could provide many more examples. The current Asociación Española de Fiestas y Recreaciones Históricas was created in the year 2000 in Cartagena. Today, the AEFRH has members in most of the regions of Spain.

These historical fairs are usually organised at municipal level, and their main identifying features are the boost given to local trade during the days on which the fair is held and the encouragement of tourism. Likewise, they facilitate the festive participation of citizens, contributing to the creation of local volunteer groups or amateur agents who act according to management criteria devised by local traders, councillors responsible for festivities or tourism, and private event management companies.

This is the context for the overwhelming proliferation of mediaeval fairs and markets, both of which are events that respond to similar criteria of organisation, management and scheduling. In general, these events almost completely lack historical rigor, and their aim, like that of the festivals of Moors and Christians, is not to communicate or interpret the past, rather they seek solely commercial, festive and recreational aims. On many occasions, events of this type are embellished with clichés of little academic value, taken from the cinema and literature. The fact that they have grown without vocation for dissemination has led to amateurism in both management and participation, creating real stereotypes of costume and impedimenta that have little or nothing to do with the periods in which they are said to be set. ${ }^{20}$ The Middle Ages are, at national level, the period that stimulates the largest number of events of this type, mediaeval markets constituting an example of a real bubble in the proliferation of pseudo-cultural by-products, representing one of the main stumbling blocks for the definitive consolidation of these manifestations as quality products.

All in all, although their interest for the conservation, dissemination and management of cultural heritage has been testimonial, it would be unfair to deny the role played by these events in Spain in this respect in recent decades, since they

19. The European Confederation of Historic Festivals and Events was founded in 1991 and it brings together associations from various countries: Confédération Européenne des Fétes et Manifestations Historiques. 1 December 2017 <http://www.cefmh.eu/>.

20. See, by way of example, Cabezas Barrios, María. La distorsión histórica y de las culturas no occidentales en las recreaciones y fiestas históricas. Valladolid: Universidad de Valladolid, 2017. 
have given rise to shrewd interests in the conservation of heritage assets where events of this type have taken place.

Unfortunately, the recreational and commercial aims of this model have been met by an almost tomb-like silence from the different professional, academic and scientific communities of the territories where they have been developed. It is currently unusual to find a heritage manager, a museum, a local study centre or a university that is behind, or even collaborating with, the design of criteria for the organisation and documentation of manifestations of this type, despite the fact that the latter are fed by and publicise the historical processes that such institutions, the majority of which are public, have as their main area of study. The complete antagonism between the academic world and citizen-led manifestations of history is such, that it is hard to believe that history and heritage have mingled with citizens such as never before, and these centres of academic knowledge, the purpose of which should be this and none other, have had nothing to do with it. Something on which we should reflect.

But in addition to all that has been argued above, it is fair to assume that the role played by many of these manifestations (historical fairs, specifically) with a view to the dissemination of mediaeval history and heritage has been and continues to be praiseworthy, regardless of the level of authenticity and historical rigor, or of the dissemination of debatably banal aspects of history compared to other more important aspects that have been left aside. One should not deny that these popular events have allowed interest in the past to grow, and history continues to be a travelling companion well into the $21^{\text {st }}$ century.

In contrast with manifestations of this type we find the model based on historical re-enactment, the majority model in the sphere of the Nordic countries, central Europe and English-speaking countries. This model, not at all at odds with the economic development of cultural industries, understands that historical reenactment should not be circumscribed to a show in the strictest understanding of the term, ${ }^{21}$ nor should it pursue strictly commercial aims. Historical fairs, thematic markets or stage shows with a historic setting do not form part of historical reenactment, insofar as they may lack scientific support in their planning and design, and their main objective is not dissemination, rather they are based on commercial, scenic or merely festive aims (notwithstanding the fact that, in some of these manifestations, dissemination also forms part of these aims unrelated to re-enactment). The model of management and dissemination of heritage based on re-enactment is characterised by a primordial interest in communicating history and cultural heritage. ${ }^{22}$ Underlying this argument is a question that is not trivial: is

\footnotetext{
21. It lacks the resources inherent to a show: scenic, spatial or technological. It is a show in the sense that it promotes intellectual contemplation and provokes delight, astonishment or other emotions.

22. For further information on organisational premises for the development of historical reenactment models in heritage assets, see: Del Barco Díaz, Miguel. "La recreación histórica...": 243254; Rojas Rabaneda, Antonio. "Herramientas y estrategias...": 89-110; Cortadella, Jordi. "Los grupos de recreación...": 91-140; Guzmán Ramos, Aldo; Fernández, Guillermina; Fernández, Silvia. “La recreación histórica como herramienta de la interpretación para recuperar y preservar el patrimonio en
} 
an academic and serious model at odds with the development of a cultural industry that can reach the general public? Not at all, as the European examples show us. Furthermore, it arises as a method that is able to offer this tool for reflection on the past. The reasoning behind this premise is that it is not sufficient to conserve and study heritage; without the dissemination and democratisation of historical knowledge a large proportion of its cultural and social value is lost. The participation of citizens is indirect and, when it is direct, it takes place via reconstruction groups or organised entities that have carried out the appropriate research.

On the other hand, it is curious to note how another of the aims sought by this model is the raising of awareness among citizens regarding the conservation of heritage assets for future generations. It is not enough merely to communicate and interpret history, rather the heritage that has been left to us should be conserved and bequeathed to the future as part of our identity; in fact, this premise is linked to the social function advocated by this model.

And, as a consequence, the creation is promoted of quality cultural products that generate flows of cultural tourism and which value and focus work on projects for historical re-enactment constituted according to professional criteria. These projects remain in contact with research groups and university departments that guarantee and support the work behind the practice.

The construction and development of quality didactic projects based on historical re-enactment, however, is not new. The model arose with what are known as openair museums, founded first in the United States and immediately afterwards in central Europe. This is the case of the city-museum of Williamsburg, in the state of Virginia. This project reproduces a real colonial city of the $18^{\text {th }}$ century, where the visitor is submerged in a space with unpaved streets, shops full of colonial products, saloons, reconstructed wooden buildings and buggies drawn by horses. The details, material aspects and dissemination are given the utmost care, in a dream-like space that is completely cultural and museographical. The visitor does not go to see a traditional museum but blends in with a living society of that century that contextualises scenes and actions in the period and responds to the nature of the town. ${ }^{23}$

Two pioneering models in Europe, similar to those of America, are Biskupin ${ }^{24}$ in Poland and Eketorp, ${ }^{25}$ Öland, in Sweden, both of which recreate ancient history. Biskupin is the scientific reconstruction of an $8^{\text {th }}$ century BC commercial city on the same Iron Age site. It is laid out in the same way as the site in the era stated,

peligro". Boletín de Interpretación, 23 (2010): 18-23; and Leon, Warren; Piatt, Margaret. "Living history museums", History museums in the United States: A critical assessment, Warren Leon, Roy Rosenzweig, eds. Urbana: University of Illinois Press, 1989: 64-97.

23. For the methodological aspects of this open-air museum: Handler, Richard; Gable, Eric. The new history in an old museum: Creating the past at Colonial Williamsburg. Durham: Duke University Press, 1997; and regarding the didactic projection of the Williamsburg model: Santacana Mestre, Joan; Serrat Antolí, Núria, eds. Museografía didáctica. Barcelona: Ariel Patrimonio, 2005: 76-78.

24. Biskupin. 1 December 2017 <http://www.biskupin.pl>.

25. Eketorp. 1 December $2017<$ http://www.eketorp.se>. 
based on a complex reconstruction project of a completely museographical nature. Its people provide live historical re-enactment and it includes spaces for scientific work at the site itself where the livestock and agriculture of the site are researched via experimental archaeology. ${ }^{26}$

Eketorp is a $1^{\text {st }}$ century AD fort, built on its own site. This reconstruction has been carried out according to scientific processes, making it another live archaeological museum where the inhabitants keep livestock, perform trades appropriate to the Scandinavian Iron Age and live at different times of the year in the same way as the culture that built this type of defensive spaces in the Baltic territories at the commencement of our era. Like Biskupin, Williamsburg and so many others, Eketorp is intended to attract visitors, communicate, educate and research. ${ }^{27}$

Similar adoptions for the Middle Ages have proliferated in Europe in more recent stages. The model based on re-enactment, as we have already seen, not only involves universities, study centres, museums and heritage managers, but, on occasions, state institutions themselves are behind the maintenance and projection of initiatives for the research and dissemination of heritage by means of this tool. We refer to consortia such as Historic Scotland ${ }^{28}$ or English Heritage. ${ }^{29}$ These organisations depend directly on the government of the United Kingdom, and their purpose is to manage, conserve and publicise a great deal of publicly owned heritage.

Such consortia usually carry out the management of heritage assets with groups, projects and companies for the teaching and dissemination of history and heritage which use re-enactment as the main vehicle. The phenomenon of mediaeval markets, historical festivals or fancy-dress parades, so typical of Southern Europe, ${ }^{30}$ have no place in this model of heritage management and promotion, which attracts millions of visitors every year and has as its main aim the diffusion of the history

26. These initiatives for historical re-enactment are inserted in larger projects such as open-air museums and in situ reconstructions of archaeological heritage.

27. For further information on the museographical, archaeological and historiographic treatment of these spaces we recommend some articles such as (Eketorp): Edgren, Bengt. “Eketorp Rediviva: 'an ongoing scientific discussion'". Museum international, 50/2 (1998): 10-15; and (Biskupin): Piotrowska, Danuta. "Biskupin 1933-1996: Archaeology, politics and nationalism". Archaeologia Polona, 35 (1997): $255-285$. Scientific literature in Spanish, in this respect and of a monographic nature, is practically inexistent. Some details may be found in: Llonch Molina, Nayra; Santacana Mestre, Joan. Claves de la museografía...: 31 38; or, tangentially, in the context arising from the discussions on the reconstructions of archaeological heritage and the social function of archaeology: Masriera Esquerra, Clara. "Las reconstrucciones arqueológicas: problemas y tendencias". Her $\theta$ Mus. Heritage $\theta$ Museography, 1 (2009): 41-49; Ruiz Zapatero, Gonzalo. "Fragmentos del pasado: la presentación de sitios arqueológicos y la función social de la arqueología". Treballs d'Arqueologia, 5 (1998): 7-34; Belarte, Maria Carme; Masriera Esquerra, Clara; Paardekooper, Roeland; Santacana Mestre, Joan, eds. Actes de la VI Reunió Internacional d'Arqueologia de Calafell. Barcelona: Departament de Prehistòria, Història Antiga i Arqueologia de la Universitat de Barcelona, 2013; and Santacana Mestre, Joan. “La arqueología experimental, una disciplina con alto potencial didáctico". Íber: Didáctica de las ciencias sociales, geografía e historia, 13/57 (2008): 7-16.

28. Historic Scotland. 1 December $2017<$ https://members.historic-scotland.gov.uk/>.

29. English Heritage. 1 December 2017 <http://www.english-heritage.org.uk/>.

30. And Spain. 
and heritage of the United Kingdom and the creation of quality cultural industries around it.

As a case in point, the most massive historical commemoration event in this country is the re-enactment of the Battle of Hastings, a contest that took place in 1066 and in which the Duke of Normandy, Willian 'the Conqueror', won the throne of England from King Harold. This great re-enactment, organised by English Heritage, brings together every year thousands of historical re-enactors from across Europe and tens of thousands of visitors. The controls of authenticity in dress, panoplies, type of arms, gold and silver smithery, equestrianism, archery, military encampment and other factors are extremely restrictive among the re-enactors, and stringent research is required and imposed for its staging. ${ }^{31}$ And all to offer the general public a quality product, covering from the least specialised consumer to the specialist, who demands a serious product. Events of this type are articulated around different actions, some of which require an entrance fee. It is, at the same time, a cultural industry in the same way as professional theatre, dance, opera or cinema, which offers the spectator a quality product with guarantees. Compared to the little-specialised event, free of charge and for entertainment such as the model referred to above, a type of industry is observed which not only offers seriousness and responsibility with history and heritage, which belong to everybody, but which employs professionals from this branch of the humanities and social sciences, undervalued in a model such as the previous one, which generates a turnover of millions of euros around history but which, paradoxically, does not require specialised labour. Furthermore, this industry is, in many cases, sustainable; that is: it is funded by the end consumer, and not by all citizens with their taxes as occurs with other models, in which case they cannot select the quality of these products when they are deployed in the streets.

Another similar initiative is the Jorvik Viking Centre ${ }^{32}$ project, created in 1984 in York, United Kingdom. The cultural consumer experiences real time travel in this space, by being taken to the era of the Danelaw, and submerged in the city of York in the early Middle Ages. The reconstruction makes it possible to visit the site itself, reconstructed with spaces from the old Viking settlement, and it even shows the work of the archaeologists, which can be visited in person and understood. The centre also has a museum, visitor centre and re-enactments throughout the year. ${ }^{33}$

A special mention is also deserved by the Guédelon project, ${ }^{34}$ which constitutes another singular open-air museum. Guédelon in itself is exceptional. Located in Treigny, France, the project involves the construction of a $13^{\text {th }}$ century castle using only the techniques and materials used in the Middle Ages. The work began in 1997 thanks to Michel Guyot, proprietor of the nearby castle of Saint-Fargeau,

31. Gapps, Stephen. "Mobile monuments: A view of historical reenactment and authenticity from inside the costume cup board of history". Rethinking History, 13/3 (2009): 395-409.

32. Jorvik Viking Centre. 2 December 2017 <https://www.jorvikvikingcentre.co.uk/>.

33. Ballart Fernández, Josep; Juan i Tresserras, Jordi. Gestión del patrimonio cultural. Barcelona: Ariel Patrimonio, 2012: 206; and in: Santacana Mestre, Joan; Serrat Antolí, Núria, eds. Museografía...: 428.

34. Guédelon. 2 December $2017<$ https://www.guedelon.fr/>. 
and will continue until 2020, when it will be fully completed. The architectonic management of the site proposed the project as the reconstruction of a castle of the era of Philip II, and its completion using strictly materials, techniques and procedures of the period. ${ }^{35}$ The project is designed, on the one hand, as a vast open-air museum based on didactics and experimental archaeology. On the other hand, as an incentive for the creation of jobs. ${ }^{36}$ It therefore involves research into mediaeval building techniques and procedures: pulleys and scaffolding of the $12^{\text {th }}$ and $13^{\text {th }}$ centuries are used, the clothes of the re-enactors/builders are those of the time, the working methods, transportation and decoration of the materials are those of the Middle Ages, and a long et cetera of factors that make Guédelon a living museum. The reconstruction is a focus of attraction for universities, schools of engineering and architecture, as well as primary and secondary schools. It is not only projected for research and dissemination, it is also becoming consolidated as a motor for tourism development: it currently attracts more than 300,000 visitors per year.

With regard to southern Europe, it should be pointed out that although the model of dissemination of heritage based on re-enactment has had, and continues to have, less impact, some projects worthy of mention are currently being developed. In the case of Spain, historical re-enactment, in general, is in the embryo stage. The authorities are not yet familiar with this resource as a vehicle for the dissemination of heritage, and the academic world has practically no relationship with this discipline. In particular, the re-enactment of the Middle Ages in Spain constitutes the most notable example of this diaspora of attention. Spanish mediaeval reenactment currently debates between its fatal permeability within a cultural model dominated by mediaeval markets and historical festivals, and the revindication of its development as a serious practice with a scientific foundation. In this latter case, it lacks far-reaching projects to grant it a position of importance at national level, being limited to decontextualized initiatives and in a totally amateur setting.

In Italy, although the structuring responds to a similar profile, there are initiatives that collaborate closely with the authorities and public research projects, such as, for example, the Rievocando platform, ${ }^{37}$ which although it brings together events and projects of different types, represents a point of reference for re-enactment groups and initiatives. Something similar is constituted by the CERS (Consortium of European Re-enactment Societies), ${ }^{38}$ an institution that is present in several European countries, but is chaired from Italy. This consortium also covers events with various profiles, and it undertakes initiatives at European level in which it encourages cultural tourism based on history and heritage.

35. Baud, Anne; Martin, Maryline. "Guédelon: chantier d'archéologie expérimentale", Actes de la VI Reunió Internacional d'Arqueologia de Calafell, Maria Carme Belarte, Clara Masriera Esquerra, Roeland Paardekooper, Joan Santacana Mestre, eds. Barcelona: Departament de Prehistòria, Història Antiga i Arqueologia de la Universitat de Barcelona, 2013: 65-72.

36. It currently supports 55 permanent jobs.

37. Rievocando. 3 December 2017 <http://www.rievocando.it>.

38. Consortium of European Re-enactment Societies. 3 December $2017<$ http://www.cersonweb.org>. 
The proliferation of cultural groups and associations in Spain dedicated to the re-enactment of the Middle Ages has been notable in recent years. However, the positioning towards the organisation of private events and actions, with a completely amateur profile, has led, in some cases, to a lack of visibility of these groups by the authorities, which rarely use them for serious projects of heritage management, cultural management and communication or regional educational projects. Some groups, however, distinguished by their professional profile ${ }^{39}$ have arisen as champions of this new model, and they enjoy visibility in documentaries or historical series and regularly attend prestigious European events. This is the case, for example, of the Clan del Cuervo, ${ }^{40}$ an association that re-enacts later Ancient History and the early Middle Ages up to the $12^{\text {th }}$ century.

Other projects have managed to bring together numerous groups around a specific era or period, generating events that little by little are beginning to enjoy visibility in the panorama of events at national level. We refer to Viking Hispania, ${ }^{41}$ a project that organises annual events attended by groups and associations from across Spain and which re-enacts, more or less accurately, the historical context of the Viking invasions in Iberia, as well as the kingdoms and territories to the north of al-Andalus in the $8^{\text {th }}, 9^{\text {th }}, 10^{\text {th }}$ and $11^{\text {th }}$ centuries.

Other initiatives did not enjoy the support of the re-enactment community, despite constituting a good start for the joining of forces in this respect with a view to encouraging a model for the authorities of which, in the majority of cases, they are directly unaware. These include the $1^{\text {st }}$ International Congress for the Re-enactment of History, which was held in Barbastro (Huesca) in 2015 and which was attended by the most prominent representatives of this model at national level. ${ }^{42}$ Despite the praiseworthy commencement, it has lacked continuity.

These are just some examples, and more could be added. However, mediaeval reenactment is also finding other focuses, such as the projects carried out in Europe with regard to the sporting practices that took place in the Middle Ages, and which are coming back to life from a re-enactment perspective. This is the case of mediaeval tournaments or jousting, a contact sport rooted in history which consists, as in the Middle Ages, of re-enacting passages of arms on horseback in which various knights fight to achieve victory. The tournaments have focused mainly on the $15^{\text {th }}$ century, and they respond to an organisational profile similar to that followed in the late Middle Ages: a celebration of an urban nature, in cities or castles, where prizes were given in cash or in kind, and in which the various members of the noble elites contested their honour in armed combat. These historical tournaments, which in the Middle Ages, paradoxically, could also be re-enactments of earlier events, acquired a sporting nature as from the $14^{\text {th }}$ century, owing to which the

39. Perhaps not to make their living from it, but in their approach: collegiate documentation and research, professional cultural management work and capacity for large-scale dissemination.

40. Cultural Association El Clan del Cuervo. 4 December 2017 <http://www.clandelcuervo.com>.

41. Hispania Vikinga. 4 December 2017 <http://hispania-vikinga.blogspot.com.es>.

42. Such as the management of the most important festival for historical dissemination in Spain: Tarraco Viva: Festival Tarraco Viva. 4 December 2018 <https://www.tarracoviva.com>. 
arms were blunted and staging protocols were established for the enjoyment of the congregated populace. In today's tournaments, even with the familiar safety measures, the stages and objectives are reproduced, that is: the aim is to dismount the adversary at a gallop in the jousting stage, to strike with blunt weapons in the tournament stage as such, or to floor him in the unmounted combat stage. All of this is performed with replicas of armours that reproduce weights, measures and designs taken from museums. Despite constituting a practice that has been well-established for years in the United Kingdom, Germany, the USA and Canada, southern Europe lacks a similar tradition, with some honourable exceptions. This is the case of Les Ecuyers de l'Histoire, ${ }^{43}$ in France, who organise one of the most famous tournaments in Europe: the tournament of l'Ordre de Saint Michel. Or the Italian company of $l^{\prime}$ Aquila Bianca, ${ }^{44}$ which belongs to the Italian Federation of Equestrian Sports. In Spain the historical festival model has promoted in recent years the creation of theatre companies that perform shows with horses that they themselves call mediaeval tournaments. However, these self-styled tournaments bear no resemblance whatsoever to the way the practice took place in the Middle Ages. Clothing can be seen in colours and synthetic fabrics typical of the festivals of Moors and Christians, an absence of historic armour (when not directly made from plastic) and stages and procedures that are not documented anywhere in Europe in reference to events of this type. However, there is a re-enactment project named Jousting Iberia, ${ }^{45}$ a pioneer at national level, that does organise completely historical tournaments and which in the last two years has implemented initiatives for the dissemination of real mediaeval tournaments in Spain, with presence at some heritage assets and at several events.

And, lastly, we will describe another sport which has experienced almost disproportionate growth in recent years, and which also has a historical foundation. As such, it is a competitive practice which does not seek to disseminate the past. However, the controls of authenticity in the armour and weapons (from the $14^{\text {th }}$ century, in general) make it a violent practice based on European martial arts. This is the case of HMB (Historical Mediaeval Battles); Combate Medieval, as it is known in Spanish; or bohurt, in French. It arose in Russia in the 1990s, and it is defined as a full-contact sport which uses offensive and defensive weapons typical of the Middle Ages, and which has specific rules for each type of historical competition, assisted by a refereeing panel that enforces the rules in both the historical and sporting sense. ${ }^{46}$ This is a violent practice where the combat is free with any type of real weapon. ${ }^{47}$ The rules stipulate which blows are not allowed, or how a combat is to be finished to win the competition. Different modes exist in this type of

\footnotetext{
43. Les Ecuyers de l'Histoire. 4 December 2017 <http://ecuyersdelhistoire.e-monsite.com>.

44. Compagnia dell'Aquila Bianca. 4 December $2017<$ http://aquilabianca.org>.

45. Jousting Iberia, historical equitation. 4 December 2017 <http://www.joustingiberia.com>.

46. Martínez Ciruelos, Jordi. Bohurt, La melé del antiguo deporte de combate medieval. Barcelona: Editorial Alas, 2014.

47. Of course, the offensive weapons do not have points or blades, although they are metallic and of all types: swords, halberds, maces, axes.
} 
tournament, and there is currently a large number of national teams from all over the world and an international association. The practice is gaining enthusiasts from all corners of the globe, and every event brings together tens of thousands of people. The latest international championships have been held in places such as the city of Carcassonne and the castle of Belmonte (Cuenca).

\section{Medieval re-enactment, the problem of heuristics}

As we have seen, the aim of historical re-enactment, in the strictest meaning of the term, is to communicate, interpret or educate on the past. However, this discipline is also a recreational practice. In either of the two cases, the projects that implement actions based on historical re-enactment consider prior research, based on historical method, to be essential.

And it is this aspect that makes this discipline a tool to be taken into account for the dissemination of the past. Historical re-enactment, without a heuristic stage of scientific method, loses its raison d'être.

How are the sources that make it possible located and compiled, and what relationship does this have with the other stages of the historical method? To respond to this question we need to understand that historical re-enactment, in itself, encounters considerable problems with regard to disseminating history beyond material culture itself. Currently, and owing to various factors, re-enactment has been unable to overcome the reductionism inherent to communicating, solely, very specific aspects with regard to clothing, impedimenta, material culture, customs, practices in disuse, ceremonial protocols, rituals or liturgies. In other words, a scene of living history is able to show and communicate what clothing was like, the table manners that were required or the nature of the combat techniques with sword and shield in the second third of the $15^{\text {th }}$ century, but it is not able to explain, alone, the context and the consequences of the founding of the Peasant Syndicate in 1440, or the evolution of writing from cuneiform to the invention of the Guttenberg press in that same period, for example. Or, to put it another way, it is not able to contextualise and explain alone complex historical processes. Owing to all of this, it is logical that from the start it has been marginalised as a practice with an educational profile, and with reservations. However, as we will see below, this construct can be overcome by endowing the practice with other complementary resources. In any case, for the dissemination of history, at any level, historical re-enactment is based on the use of primary and secondary sources.

It would be appropriate to expect this practice to be informed mainly by secondary sources, but it is no less true that the historiography relative to the aspects of the past that constitute the back bone of re-enactment (material culture, especially) is not exactly abundant. Historiographic production on daily life underwent growth as from the birth of the concept of total history, something that occurred a few decades ago. Furthermore, other ancillary disciplines of mediaeval history, such as 
archaeology, have had a relatively short life in southern Europe. For this reason, the heuristics that feed historical re-enactment, and specifically that which focuses on the Middle Ages, are based not so much on historiography and other secondary sources as on iconographic and archaeological sources and, to a lesser extent, documentary sources. That is: on primary sources.

Documentary sources provide and have provided historical re-enactment not only with knowledge regarding elements inherent to the material culture, but the designation used in the era for the elements to be reconstructed, their origin, their monetary value or how they were made. Therefore, it is not unusual to see that the sources of the re-enactors include diplomatic collections of institutions and congregations, trade or administrative documentation, and so many others that inventoried clothing, food, arms, armours, domestic items, military devices; as well as treatises on war, science, herbalism, poliorcetics, etc. The vision of this documentation, in many cases, examines in depth aspects that other researchers may consider trivial or irrelevant for their objects of study. However, it should not be overlooked that the information provided by documentary sources is textual and not visual. This allows the gathering of important but not essential knowledge for reconstruction. To reconstruct history we need, essentially, other primary sources such as iconography and mediaeval archaeology.

Consequently, a considerable proportion of the work of the researcher who is to re-enact history is centred on museums, heritage assets and others. This prerogative is complied with in theory, and sometimes not completely in practice. Currently, the historical re-enactor of the Middle Ages lacks in many aspects the assumption of a minimally professional research methodology. This is due, to a great extent, to his or her amateur profile. Although re-enactors assume that their practice is for dissemination, in reality they pursue it recreationally or as a hobby, leaving in second place rigorous processes of research of sources, as well as professional methodologies of dissemination and communication.

In this respect, mediaeval re-enactment in Spain suffers from some defects which it is necessary to overcome in order to provide the discipline with more rigor. On the one hand, the habit of the average re-enactor, with little training, of adopting elements seen in other re-enactors, without checking whether they are correct for the period; this often occurs with regard to re-enactors from other latitudes, whose cultures have nothing to do with our own which we wish to reconstruct. On these occasions, this practice implies the use of directly anachronic replicas. On the other hand, the re-enactor lacks a theoretical foundation for research into history and heritage, and is therefore unaware of: how to organise the archaeological material found at the sites; which collections are shown or stored by the museums, or which ones are (or not) inventoried; which publications or archaeological charts describe the sites that yielded archaeological remains of the period to be re-enacted; or the current knowledge with regard to the type of these materials and these sites. The lack of knowledge in some cases of procedures and resources that any researcher uses implies a reduction in the quality of the reconstruction of the Middle Ages. 
Not only this. To the above reflection it should be added that a reconstruction of the mediaeval era involves confronting discussions on cultural details or elements that the archaeological or documentary sources do not discern, therefore it becomes necessary to take iconography as a first-hand source. In fact, it is possible to affirm that this constitutes the principal documentation in Spanish mediaeval reenactment. Among the groups there is a proliferation of home-made manuals and digital photographs that only show iconographic sources to inform on how to dress or arm oneself; archaeology, on many occasions, is not added to these manuals. It is true that iconography allows us, on the one hand, to bridge the gaps left by archaeology, especially in relationship with perishable materials; but on the other hand it also favours the creation of idealised static images that entail the establishment of axiomatic models for the re-enactment community, the authenticity of which should be subjected to serious historiographic debate.

In general, the iconographic sources to which the mediaeval re-enactors have recourse to reconstruct the past are illuminated manuscripts, sculptural images and pictorial works, in different media.

Iconography currently receives two definitions: 1) the branch of art history concerned with the description and interpretation of that which is represented in the work of art, and 2) the subsidiary discipline of history concerned with the detailed study of the contents of the work of art, treating it as though it were a document. ${ }^{48}$ Historical re-enactment takes this second definition within the method implemented in its documentation. However, it is important to understand that iconographic analyses of mediaeval art begin with the symbolic nature of the image in the analytical premises of any artistic figure..$^{49}$ In any analysis of sources of this type methodologies are implemented based on semiotics and hermeneutics, ${ }^{50}$ an aspect that, although it is usually ignored by the mediaeval re-enactor, should not be taken lightly, since sometimes we forget that the mediaeval image is in itself a symbol and not a faithful representation of reality. We should not ignore the importance of the symbol and its significance in relationship with the era, the place, the recipient or the training of the artist; furthermore, the majority of mediaeval iconography is a phenomenon in the service of religious power. ${ }^{51}$

Thus, it is necessary to take the reconstruction of material culture on the basis of an artistic representation knowing the nature inherent to the work of art. If we

48. Santo Tomás Pérez, Magdalena. Las imágenes como fuente para el estudio de la Historia. Valladolid: Castilla Ediciones, 2009.

49. Regarding symbology and duality in mediaeval iconography, see: Baschet, Jérôme. L'iconographie médiévale. Paris: Editions Gallimard, 2013: 15 and ss.

50. In fact, the bases of iconographical analysis of art can be located in the work of Erwin Panofsky, who considers three methodical levels in the analysis of any artistic image: 1) Pre-iconographical description, where the meaning of the phenomenon is captured to enable it to be described in its most technical aspect. 2) Iconographical analysis. To look in greater depth at the motives and meaning of the work and identify it with total precision. 3) Iconographical or iconological interpretation. The objective is to capture the deeper meaning of the work. Panofsky, Erwin. El significado en las artes visuales. Madrid: Alianza, 1995, 51 and ss.

51. Baschet, Jérôme. L'iconographie...: 18. 
study to reconstruct the Middle Ages taking iconography as a source, it is necessary to adopt a prior research methodology that considers: 1) the real symbology of the image and 2) the identity of the artist, or at least his social background and whether he is presumed to have knowledge of the image he is representing. Only in this way will we validate the reliability of the source.

Therefore, we define the heuristic problems of historical re-enactment around four basic problems, which we will set out below. The first is what is known as The problem of reality. This is related to the intention of the mediaeval artist, which is not to represent images of the period with a high level of detail, but to use them to transmit a symbology, a message. The image is not the work in itself, but the symbol that this transmits. This problem may arise, for example, from the fact that the artist sculpts or illuminates details of costume or tools of daily life according to trivial and non-exhaustive aesthetic solutions. We insist: the authors do not set out to show reality with realism, but to communicate messages.

The second is The problem of imagination. Illuminated manuscripts, for example, were produced in strictly monastic contexts, however they are the most used sources for researching down to the last detail the impedimenta of armed men. The monks could have very limited knowledge regarding how $12^{\text {th }}$ century knights carried their weapons, how their aventails or mail coifs were made, or which harnesses were worn by a war horse. However, the images from codices copied by monks are taken as unquestionable references to military sources, even when the references that inspired them to illuminate war scenes are unknown. Added to this randomness is the fact that some manuscripts were copies of the originals, which would have led to important changes with regard to the initial images. It is important to take into account that the author of the iconographic sources may have limited knowledge of what he is reproducing, and this leads to inventions in the work or solutions based on his imagination. If we reconstruct and show an element taken from a source whose author imagined it owing to lack of knowledge, we are assuming as real something that never existed.

A third reference is The problem of territoriality. This conditioning factor occurs when we take as valid an iconographic source by an author who reproduced it at a distance of hundreds or thousands of kilometres from the society we wish to recreate. The problem is revealed in illuminations, capitals, friezes or frescos. It is evident that the modes of dress, as well as other customs, were not the same everywhere. Many garments were worn in the Kingdom of Aragón in the $13^{\text {th }}$ century, but are not documented in Bourgogne, for example. What is valid for one territory many not be correct for another. And this is aggravated when the production of some sources, as in the case of illuminated manuscripts, takes place in specialised workshops, and these served different territories of the Christian world. We have a case for this problem in the Vidal Mayor, which is conserved in the Museum of the J Paul Getty Trust. ${ }^{52}$ Professor Lacarra Ducay says of this codex:

52. Santa Mónica, California. 
Estudiadas analiticamente las ciento cincuenta y seis miniaturas y sus decoraciones marginales confirman su parentesco con obras realizadas en territorio francés o en el sudeste de Inglaterra que constituyen, con las parisinas, una sola familia. A todas ellas cabe incluirlas dentro del llamado "Estilo inglés del Canal", para expresar "el conjunto de caracteres comunes, independientemente de las diferencias locales. ${ }^{53}$

If this is so, the manuscript would have been produced in a scriptorium of the south of England or the north of France. Curiously, mediaeval re-enactors take its miniatures as an idealised example of Aragonese and Catalonian characters of the second half of the $13^{\text {th }}$ century, when the person who illuminated them, in all probability, took as models the people where he lived. There are even cases of reenactors who reproduce the type of capiello ${ }^{54}$ which appears in its illuminations, inexplicably flattened and contracted, without stopping to think about whether this garment was really like this or whether, as all would seem to indicate, it responds to artistic licence in the author's representation.

The last of the four problems with regard to the heuristics of re-enactment is The problem of a-temporality. No historical re-enactor would incarnate a Roman soldier of the $1^{\text {st }}$ century AD armed with a coselete ${ }^{55}$ of the $16^{\text {th }}$ century, and yet it is in this way that many frescos and pictorial works show the Roman legionaries in the Passion of Christ during the Renaissance. As a general rule, artists reproduce in their works scenes identical to how they were in the reality of their own time. Mediaeval artists had no cultural constructs that enabled them to know how characters from the past dressed or armed themselves, therefore the characters from the Bible appear dressed in a way that is similar to how people dressed at the time they were painted or sculpted. This, which up to a point seems obvious, represents a problem when the artists represented past moments that are not so far back in time as, for example, passages of the New or Old Testament. This is the case, for example, of the murals in the Aguilar palace (Barcelona), ${ }^{56}$ and which reproduce the conquest of Mallorca by the feudal troops of Jaime I. The frescos are dated at between 1285 and 1290, and they narrate events that took place between 1229 and 1231. Despite this chronological difference, the historical re-enactment groups that reconstruct the first third of the $13^{\text {th }}$ century base their inspiration on these paintings with regard to weapons, armour and escutcheons. Sixty years passed

53. "Analytical studies of the one hundred and fifty-six miniatures and their marginal decorations confirm their relationship with works produced in French territory or in the south-east of England which constitute, with those of Paris, a single family. All of these can be included in what is called the English 'Channel style', to express 'the set of common characters, regardless of local differences'". Lacarra Ducay, María del Carmen. "El manuscrito del Vidal Mayor. Estudio histórico-artístico de sus miniaturas", La miniatura y el grabado de la Baja Edad Media en los archivos españoles, María del Carmen Lacarra Ducay, ed. Zaragoza: Institución Fernando el Católico, 2012: 20.

54. A hat or cap worn by men in the $13^{\text {th }}$ century.

55. Half armour worn by the infantry of the modern era. The term is also used to denote members of the Spanish infantry regiment armed with this half armour, who usually held, owing to their veteran status, the most important positions in battle formations.

56. Currently in the Museo Nacional de Arte de Catalunya. 
between the event represented and the production of the paintings, which makes it practically unthinkable that the authors preceded the artistic act with research to know what the panoplies of the knights and warriors during the conquest of the island were like. That is to say, it is very likely that they painted on the basis of the reality of their own era, that of 1290 . Therefore, they reproduced a historical scene sixty years later, representing a technology contemporary with their work and not with the time of the conquest.

\section{Medieval re-enactment, the problem of methodology}

The interest in mediaeval re-enactment in the Mediterranean area has grown in recent years from a military perspective. The taste for recreating elements and constructs of military culture has left other aspects of this period to one side. It is no less true, moreover, that recently an incipient growth has been seen of amateur groups who stage other modes of re-enactment related to civilian life: daily life (of the different social classes), religious models (sacramental rites, ceremonies, eucharists...) and other civilian events (such as coronations, banquets, tournaments...).

From this military perspective, the mediaeval military re-enactment enthusiast usually carries equipment constituting what are known as fencing foils, characterised by reproducing historical models with no blade or point. At European level there are various regulated systems of sporting combat with prohibited bodily targets and other conditioning factors in the interests of safety. Likewise, it is appropriate to mention the growth in military practices related to Historical European Martial Arts, a sporting practice based on historic documentation which reproduces combat techniques with European weapons of the Middle Ages and the Modern Age. Its practitioners are organised in associated schools and academies, which are overseen by international bodies, such as the Academy of European Medieval Martial Arts. This entity defines its work and that of those who pursue this discipline as:

[...] focused on the research, reconstruction and resurrection of authentic mediaeval combative systems (armed, unarmed, armoured and unarmoured), firmly based on the works of the late 14th century Friulian swordsmaster by the name of Fiore dei Liberi, demonstrating the deadly practicality and effectiveness of the art as it applies to today's personal self-defence. ${ }^{57}$

It is also true that the regulatory requirements with regard to safety blur in some way the total approximation to mediaeval combat, since they prohibit stabs and other fundamental blows in the martial procedures of the era. This, however, has

57. Academy of European Medieval Martial Arts. 4 December 2017 <http://www.aemma.org>. 
not concealed the capacity of these practices to communicate other elements such as combat tactics. ${ }^{58}$

Regardless of this interest in all things military, it is true to say that in Spain those who practice mediaeval re-enactment adduce that they implement methodologies close to historical method, to dissemination and, ultimately, experimental archaeology. Because the discipline not only allows history to be communicated for a better understanding, but it also serves as a means of research.

Experimental archaeology has become in recent years an extremely valuable discipline to interpret the past, now constituting a fundamental piece in the study of pre-history. However, it is necessary to understand that the information it provides differs to a large extent from that offered by other procedures, ${ }^{59}$ and that the form of assumption and insertion in the scientific method will affect the interest that this may provide to any research. In relationship with historical method, the assumption of experimental archaeology to research the mediaeval era is an almost unheard-of practice, taking into account that it deviates considerably from traditional research procedures. In any case, and despite constituting a procedure to be explored, the mediaeval re-enactor may experience, from a purist praxis, aspects related to food, hygiene, military organisation or the manufacture of elements using techniques of the era, among other things. ${ }^{60}$ We must not forget that to implement didactic experiences that teach the past, experimentation has been shown to be one of the most important tools, ${ }^{61}$ as already introduced by Dewey, for modern educational currents. Aside from these possibilities, it is no less true that in Spain the mediaeval re-enactor assumes little scientific vocation; the amateur communities lack connections with the world of research and an interest in disseminating serious studies in this respect in scientific circles.

Because if there is one thing that characterises the methodological premises of the practice of mediaeval historical re-enactment in Spain it is its amateurism. Although this factor seems to be an obligatory condition of the performers, which they proclaim and respect, the fact is that the non-specialised dedication to this discipline leads to a deficit of professional rigor in such important components such as communication, dissemination, didactics, cultural management, research or the publication of research results, in the case of a hypothetical experimental archaeology. Some mediaeval historical re-enactment groups have achieved good levels in reproduction of material culture of the Middle Ages, but they lack professional aptitudes that enable them to communicate with quality; they do not

58. Balbás, Yeyo. “La Recreación...”.

59. Baena, Javier. “Arqueología experimental, algo más que un juego”. Boletín de Arqueología Experimental, 1 (1997): 2-5. Also interesting, in this respect, is the in-depth work and reflection in: Reynolds, Peter; Espadaler, M. Pilar. Arqueología experimental: una perspectiva de futuro. Barcelona: Eumo, 1988.

60. Santacana Mestre, Joan. "La arqueología experimental...": 8-11. We should not forget, as we will analyse below, its value as an element not only for research, but also for didactics: Martín Piñol, Carolina. “La Edad Media: entre la empatía y la experimentación”. Íber: Didáctica de las Ciencias Sociales, Geografía e Historia, 13/57 (2008): 52-59.

61. Gómez Cardona, Gemma; Feliu Torruella, Maria. “Arqueología, vivencia y comprensión del pasado". Iber: Didáctica de las ciencias sociales, geografía e historia, 78 (2014): 15-25. 
know the fundamental principles of didactics to show the past with rigor, or they follow organisational norms that do not obey cultural management methods for the development of quality projects. Aptitudes that are necessary, however, in any profession related to the dissemination of heritage.

This conception of re-enactment as a hobby generates a praxis with a private profile, where the re-enactor acts philanthropically and for himself, constituting himself as the centre of the practice. People currently re-enact because they enjoy doing so, as a pastime, consequently relegating to second place all that is related to a quality dissemination and communication of knowledge from a scientific perspective. Although there are many groups and individuals who do follow a scientific documentation procedure, the methodologies that they use to put it into practice show that what they are doing is, purely and simply, practicing a hobby.

In this respect, the proof of this is the inadvertence among cultural programmers and heritage managers of the re-enactment world. The latter, to a certain extent, is usually more concerned with organising events of a private nature (or public, but with reservations) to enjoy re-enactment as a private hobby. Something which explains, to a large extent, the scant acceptance of the model from the Englishspeaking world in cultural dissemination structures of Spain.

\section{Conclusions and inertia: towards a horizon based on didactics}

It is necessary to analyse the factors that bring mediaeval re-enactment close to didactics, but also those which separate it. Examining in depth the psychosocial aspects of the human being in past eras through the practices inherent to them may help us to understand how they lived. However, the past constitutes a time that will not return, owing to which it is impossible to reconstruct a moment that did not have the same physical, psychological, temporal, spatial or social conditioning factors as those with which, irremediably, we set out to approach it at the present time. We are totally limited by the paradigm with which we interpret the present, ${ }^{62}$ and this makes it impossible, obviously, to take up again moments that will never return. Therefore, as a tool to approach the past with the aim of studying it, we must consider its good points but also its limitations.

This approach may change when we use historical re-enactment as a method to disseminate research results. In fact, any re-enactment is based, in itself, on prior research, whether or not this was carried out by the re-enactor himself. Therefore, re-enactment is a good method of dissemination of the past, with the

\footnotetext{
62. These reflections on re-enactment as a tool to research history are expressed with mastery by A. Cook, who discloses the fever experienced in recent years by English-speaking channels to offer historical documentaries for the general public which, on occasions, lack the scientific rigor they deserve, when they are not wrapped with an air of modern reality. Cook, Alexander. "The use and abuse of historical reenactment: thoughts on recent trends in public history". Criticism, 46/3 (2004): 487-496.
} 
conditioning factors to which we have referred. It is appropriate not to leave to one side the didactical conception of any current construct of a period of history. Because the communication of scientific knowledge is no guarantee, in itself, that learning exists. In order for mediaeval re-enactment to include didactics, it must be adapted according to the methodologies inherent to this discipline, even in informal teaching-learning environments. Any public practice of mediaeval re-enactment becomes de facto a museographical resource, insofar as it sets out to show aspects of the past by means of the practices experienced. Owing to all of this, from a fully didactic dimension, this teaching-learning process is being experienced by both the re-enactor himself and by the public. ${ }^{63}$ But to make mediaeval re-enactment an ample transmitter of knowledge we must not reduce it to its practice alone, since very few people will have time for this. It is necessary to involve cultural consumers to enable them to touch, see and feel directly an approach to the past that is as rigorous as possible. This should not prevent us from thinking that the practice in itself of mediaeval re-enactment may be a tool of great value for the learning of history in formal educational contexts, ${ }^{64}$ especially considering that it allows us to work on the most important aspect to be considered in the teaching of history, which is none other than empathy.

In any case, is the re-enactment of mediaeval scenes useful to educate on this historic period? Not alone. In order for there to be a context of teaching-learning in informal settings strategies must be in place based on principles inherent to didactics, that take into account the previous knowledge of the audience, otherwise it would be impossible to approach significant learning. We can recreate a bureaucratic office of the late Middle Ages and teach the units of measurements that were used in an Aragonese corn exchange of the $15^{\text {th }}$ century, but, if our audience does not know what a corn exchange was and what its functions were, it will be difficult for us to communicate how grain was calculated, stored and administered in that era. Therefore, it is necessary to know our audience in order to prepare a museographical script according to their knowledge, and for our discourse on what is re-enacted to be based on this. ${ }^{65}$

It is also necessary to reconstruct with a view to appealing to emotions, since without feeling there is no learning. If we reconstruct aspects related to Albigensian heresy but we do not prepare an oral and visual discourse that appeals to the empathy and emotions of the audience, it will be difficult to communicate why it was persecuted. It is also appropriate to establish different levels of communication to enable us to address different audiences, or, ultimately, to prepare scenes of reenactment that allow us to move from the simple to the complex, and in this way introduce concepts of greater complexity to those who are not familiar with the

\footnotetext{
63. Jiménez Torregrosa, Lorena; Rojo Ariza, María Carmen. "Recreación histórica y didáctica". Iber: Didáctica de las ciencias sociales, geografía e historia, 78 (2014): 36.

64. Martín Piñol, Carolina. "La Edad Media: entre la empatía...": 53.

65. Many of these principles bear a close relationship with those of didactic museography. See: Santacana Mestre, Joan; Serrat Antolí, Núria, eds. Museografía...: 89-96.; and Llonch Molina, Nayra; Santacana Mestre, Joan. Claves de la museografía...: 14-15.
} 
historical period we are trying to show. We should not present only concepts in the teaching of time, but also procedures. ${ }^{66}$ It will serve us no purpose to say that something was so, if we do not explain how we have arrived at that knowledge. Explaining and even showing the techniques used by the historian to know about the past introduces the audience to the same historical knowledge. If we know how to implement this in the very processes of historical re-enactment, we will be providing our proposal with rigor and professionalism. What is clear is that codifying a scene by merely behaving stringently as in a certain era, converts the re-enactment event into something unintelligible and hermetic, difficult for the audience to understand, however rigorously it is done. If we want to educate, it is necessary to step out of history as well as to be able to explain it from inside.

To achieve complex levels of professionalism in the design of any didactic discourse in a historical re-enactment it is convenient to know which habits bring us closer to a full educational process, and which, although they enrich our practice, take us further away. This is the case of this debate on historic rigor. The assumption of an obsessive and maximum rigor may distance us from our objective of disseminating knowledge with quality. In fact, paradoxically, the most prestigious groups in Spanish mediaeval re-enactment have achieved their reputation through adherence to this rigor, but not for their work of dissemination, which is practically unknown. A cultural audience is more satisfied when a reenactment is able to reconstruct and explain paradigmatic constructs of the past time, and not so much that it centres ad infinitum on details of a high level of rigor, such as the size of the backstitches in a bliaut, the number of seams in a coif or the composition of the fabric of an alms purse. Historical rigor is necessary and unavoidable but, by glossing over details that nobody is going to value, more effort can be dedicated to designing procedures that allow the knowledge to reach as many people as possible, and in the most didactic manner possible. Purism, understood as something natural and indissoluble in historical re-enactment, should be a quality at the same level as the capacity of communication, didactical vocation or staging, not something that is superior to them. Until this conception is overcome and the re-enactor understands that just as important as rigor is the adoption of strategies that allow it to be communicated with quality, the reenactment phenomenon will not cross the boundaries of the private sphere to become a practice understood by all and for all.

And, lastly, it is no less important to point out, as we indicated at the beginning of the article, that mediaeval re-enactment should be capable of overcoming the reductionism of the partial dissemination of the past. This practice should overcome the aseptic practice of replicating objects and artefacts of the mediaeval past. It is necessary to construct historical re-enactments endowed with discursive resources that inspire the dissemination of more elaborate aspects of the historic time, such as procedures, skills or customs (whether fencing, ancient languages, calligraphy, mediaeval Latin, equestrianism, metalwork or fabric dying). And, at

66. Santacana Mestre, Joan; Serrat Antolí, Núria, eds. Museografía...: 92. 
the same time, these discourses should be capable of showing complex processes of history, such as causes and consequences, political circumstances or legal structures. With professional strategies, quality in the discourse and a predisposal to adopt the principles of didactics, this tool may serve to educate and democratise complex concepts that, normally, only concern scholars of the subject. 